\title{
Pengembangan Media Pembelajaran Permainan Ular Tangga Untuk Meningkatkan Motivasi Belajar Siswa dan Hasil Belajar IPS di Madrasah Ibtidaiyah
}

\author{
Amifatuz Zuhriyah*1 \\ ${ }^{1}$ Sekolah Tinggi Aagama Islam Daruttaqwa Gresik \\ e-mail: zamifatuz@staidagresik.ac.id
}

Submitted: 16-07-2020 Revised : 19-08-2020 Accepted: 17-09-2020

\begin{abstract}
The teacher is the main axis of education to determine the progress of a country in the future in general, the teacher's job is to provide insight or teach knowledge to students so that they have knowledge and skills in each subject area. In addition, teachers also have the responsibility of educating students to have good attitudes and behavior, whether in the school environment, at home or in the community environtment. The learning media for this game of snakes and ladders in social science learning or abbreviated as (IPS) in elementary schools / madrasah ibtidaiyah, this media is to increase student motivation and student learning outcomes. One of the problems of education is the lack of facilities and infrastructure so that a teacher is required to be as creative as possible in improving the quality of learning in class, such as developing learning media. One of them is learning media that is interesting and overcomes the boredom. Of a student in learning activities, namely learning based on the game of snakes and ladders in social science learning.
\end{abstract}

\begin{abstract}
Abstrak: Guru merupakan poros utama pendidikan untuk menjadi penentu kemajuan suatu negara di masa depan secara umum, tugas guru yakni memberikan wawasan atau mengajarkan ilmu kepada siswa siswi agar memiliki pengetahuan dan keterampilan dalam masing-masing bidang pelajaran. Selain itu guru juga mempunyai tanggung jawab dalam mendidik siswa agar mempunyai sikap dan tingkah laku yang baik, entah dalam lingkungan sekolah, rumahan ataupun dalam lingkungan masyrakat. Media pembelajaran permainan ular tangga ini dalam sebuah pembelajaran ilmu pengetahuan sosial atau disingkat menjadi (IPS) di sekolah dasar / madrasah ibtidaiyah, media ini untuk meningkatkan motivasi belajar siswa dan hasil belajar siswa. Salah satu masalah pendidikan yaitu minimnya sarana dan prasarana sehingga seorang guru dituntut untuk sekreatif mungkin dalam meningkatkan kualitas pembelajaran dikelas, seperti mengembangkan media pembelajaran. Salah satunya media pembelajaran yang menarikdan mengatasi kebosanan seorang siswa dalam kegiatan belajar yakni pembelajaran berbasis permainan ular tangga dalam pembelajaran ilmu pengetahuan sosial ini.
\end{abstract}

Keywords: Learning Media, Learning Motivation and Student Learning Outcomes

https://doi.org/10.31538/attadrib.v3i2.110

How to Cite Zuhriyah, A. (2021). Pengembangan Media Pembelajaran Permainan Ular Tangga Untuk Meningkatkan Motivasi Belajar Siswa dan Hasil Belajar IPS di Madrasah Ibtidaiyah. Attadrib: Jurnal Pendidikan Guru Madrasah Ibtidaiyah, 3(2) 26-32

\section{INTRODUCTION}

Belajar merupakan sesuatu proses aktivitas mendapatkan informasi dari berbagai macam sumber, ataupun aktivitas yang dilakukan untuk menekuni suatu perihal supaya menggapai tujuan 
yang ingin di impikan dari sebuah pengalaman yang diperoleh, sehingga berlangsung perubahan perilaku (Abidin, 2014; Kesuma, 2011). Aktivitas belajar bisa dicoba dimanapun juga, asalkan pembelajaran tersebut merasa aman, nyaman serta menunjang dalam aktivitas belajar. Tetapi juga aktivitas belajar secara resmi dilaksanakan didalam sekolah, dimana sekolah tempat pertemuan seorang guru dan siswa dalam aktivitas pendidikan(John W, 2015; Johnson \& Johnson, 2008).

Sekolah merupakan suatu proses kegiatan memperoleh sebuah informasi dari berbagai sumber atau kegiatan yang dilaksanakan untuk mempelajari pelajaran agar mencapai tujuan yang diinginkan dari pengalaman yang diperoleh, sehingga terjadi perubahan perilaku, kegiatan belajar dapat dilakukan dimanapun, dirumah, disekolah dan lain-lain, asalkan pembelajaran tersebut terasa nyaman dan mendukung dalam kegiatan belajar tersebut. Namun, kegiatan belajar formal itu dilaksanakan didalam sekolah, dimana sekolah tempat pertemuan guru dengan peserta didik dalam sebuah kegiatan pembelajaran(Archard, 2002; BK, 2018; Rosyad \& Maarif, 2020).

Ilmu pengetahuan sosial adalah sebuah bidang studi yang dimana mempelajari dan menganalisis gejala maupun masalah sosial yang ada di dalam masyarakat, ditinjau dari berbagai aspek kehidupan secara terpadu, atau juga ilmu pengetahuan sosial bisa disebut dengan ilmu yang mempelajari semua konsep-konsep yang berkaitan dengan kehidupan seorang masyarakat dan lingkungannya. Selain itu lagi ilmu pengetahuan sosial mempelajari mengenai cara agar dapat mampu berpikir dengan kritis dan logis, mampu memecahkan sebuah masalah di dalam lingkungan dan keterampilan dalam kehidupan sosial (Utari \& Degeng, 2016).

Ilmu pengetahuan sosial bertujuan untuk membina anak didik menjadi warga negara yang baik, memiliki keterampilan dan kepedulian sosial bagi dirinya, masyarakan dan negara. Selain itu ilmu pengetahuan sosial bertujuan untuk mengembangkan sebuah potensi siswa agar tahu terhadap masalah-masalah sosial yang terjadi di masyarakat dan terampil mengatasi setiap semua masalah yang terjadi di kehidupan sehari-hari, baik yang menimpa dirinya sendiri maupun masyarakat. Berdasarkan sebuah pendapat tersebut dibidang studi ilmu pengetahuan sosial bertujuan untuk mendidik siswa agar menjadi warga negara yang baik dan bisa memiliki keterampilan sosial yang berakhlak mulia dan bertanggung jawab pada diri sendiri maupun negara(Schweitzer \& Schreiner, 2020).

Pelaksanaan pendidikan tentunya tidak sangat mudah dalam mencapai sebuah tujuan pendidikan nasional, permasalahan pendidikan di indonesia begitu sangat kompleks, salah satunya permasalahannya yakni siswa kurang termotivasi dalam belajar, hal ini sesuai pernyataan (Alma, 2013),"pembelajaran ilmu pengetahuan sosial merupakan pembelajaran yang sangat membosankan sekali”.

Pembelajaran ilmu pengetahuan sosial agar tidak membosankan menerapkan model pembelajaran berbentuk permainan ular tangga. Ular tangga itu permainan yang menggunakan sebuah dadu untuk menentukan berapa Langkah yang harus dijalani dibidaknya, peramainan ular tangga ini termasuk dalam ketegori permainan papan, sejenis dengan mainan monopoli, ludo dan lainnya. Permaianan ular tangga itu bersifat sangat ringan, sederhana, mendidik, menghibur dan sangat interaktif jika dimainkan bersama-sama dengan cara yang positif.

Media pembelajaran tidaklah mudah, karena harga media pembelajarancukuplah mahal bagi sekolah- sekolah tertentu, dalam artian semua sekolah mampu untuk menyediakan media pembelajaran dalam mendukung kegiatan belajar dan mengajar. Permasalahan tersebut tentunya menuntuk guru untuk sekereatif mungkindalam proses kegiatan belajar mengajar, sehingga proses kegiatan belajar dan mengajar tetap berjalan deng baik dan benar (Arumsari, 2017; Supriyanto, 2018).

Media pembelajaran yang inovatif dapat menjadikan sebuah alternativ bagi seorang guru untuk menyampaikan sebuah pembelajaran atau materi dengan lebih banyak varian(Aprilianto \& Mariana, 2018; Permadi \& Adityawati, 2018). Media pembelajaran sejatinya adalah sebuah alat bantu proses belajar mengajar. Segala suatu yang bisa digunakan untuk merangsang sebuah pikiran, perasaan, kepedulian serta keahlian ataupun keterampilan seorang siswa sehingga bisa 
mendorong terjadinya suatu proses belajar mengajar(Darmawan, 2014; Ngalim, 2006; Triyanto et al., 2013).

\section{HASIL DAN PEMBAHASAN}

Usaha-usaha seorang guru dalam sebuah pembelajaran siswa merupakan bagian dari usaha yang sangatlah penting untuk mencapai sebuah keberhasilan tujuan yang telah direncanakan. Oleh karena itu pemilihan strategi metode dan pendekatan diri kepada siswa sangat penting untuk mengetahui sebuah karakter siswa yang di ajar, agar seorang guru tahu strategi dan metode apa yang cocok dalam pembelajaran dengan tujuan untuk menarik perhatian siswa tersebut.

Pada umumnya, pembelajaran tatap muka memliki berbagai system tergantung dari pematerinya. Terkadang pemateri yang menggunakan metode pembelajaran seperti biasa dapat membuat pendengarnya merasa bosan dikarenakan sistem pembelajarannya yang menurutnya kurang menarik dan membosankan. Oleh karena itu perlunya pengembangan system pembelajaran yang dapat menarik perhatian para pendengarnya, salah satunya dengan pembelajaran IPS dengan menggunakan metode permainan. Metode pembelajaran berbasis permainan merupakan salah satu metode yang digunakan untuk menyampaikan materi tetapai dengan melalui metode permainan, salah satu alasan mengapa metode permainan diterapkan.

Prinsipnya karakteristik anak-anak cenderung lebih suka bermain. Maka metode permainan merupakan suatu cara yang digunakan guru untuk menyampaikan pelajaran dengan menciptakan suasana yang menyenagkan, srius tetapi santai dan tidak membosankan, namu tidak mengebaikan pembelajaran yang dilakukan, oleh karena ketika siswa merasa bosan disaat materi di jelaskan atau ketertarikan dalam rasa ingin belajar menurun, metode ini sangat penting untuk kembali meningkatkan rasa ketertarikannya dalam belajar. Dalam melakukan metode permainan diperlukan bahan atau alat bermain yang edukatif, sehingga pembelajaran dengan menggunakan metode permainan terlihat menjadi lebih menarik, mungkin salah satunya bisa menggunakan permaian ular tangga.

Ular tangga merupakan permainan untuk anak anak yang dimainkan oleh 2 orang atau lebih, papan permainan ular tangga dibagi dalam kotak-kotak kecil dan dibeberapa kota terdapat tangga dan ular yang dapat menghubungkan dengan kotak-kotak lainnya. Dan cara menjalankan permainannya menggunakan media dadu. Setiap pemain mulai dengan bidaknya di kotak pertama atau kotak start, cara menjalankannya menggunakan media dadu.

Dadu berasal dari Bahasa latin yaitu datum yang berarti sesuatu yang diberikan atau dimainkan. Dadu adalah sebuah objek kecil yang umumnya berbentuk kubus yang digunakan untuk menghasilkan sebuah angka atau simbol acak, biasanya dadu ini pada setiap sisi terdapat sebuah simbol berupa angka ataupun di tandai dengan sebuah titik antara 1 samapai dengan 6. Cara memainkan dadu lempar keatas papan ular tangga dan ketika angka dadu yang dilempar sudah muncul, pemain bisa menjalankan bidaknya sesuai dengan angka dadu dan apabila bidaknya berhenti di kolom kotak yang terdapat gambar tangga maka tandanya naik, maka pemain harus naik ke ujung tangga dan apabila bidak pemain mendarat di kolom kotak yang terdapat ular dan terletak di kepala ular, maka tandanya turun, jadi pemain harus turun atau menuju ke ekor ular tersebut.

Metode Pembelajaran dengan Ular Tangga yang di gunakan kali ini, disetiap kolom kotak ular tangga antar kolom 1 sampai dengan kolom 35 terdapat gambar dan juga materi. Konsep penggunaan media pemeblajaran ular tangga yakni dengan dimainkan oleh $4-5$ siswa. Langkah pertama yakni mulai dari start, setiap pemain harus melempar dadu saat akan melangkah ke step berikutnya dan pemain melangkah sesuai dengan angka yang didapat dari dadu, sehingga seorang siswa bisa memperoleh informasi mengenai konten materi pembelajaran maupun tujuan yang ingin dicapai. 
Contoh media pembelajaran media permainan ular tangga seperti berikut:

Gambar 1. Media Pembelajaran model Ular tangga

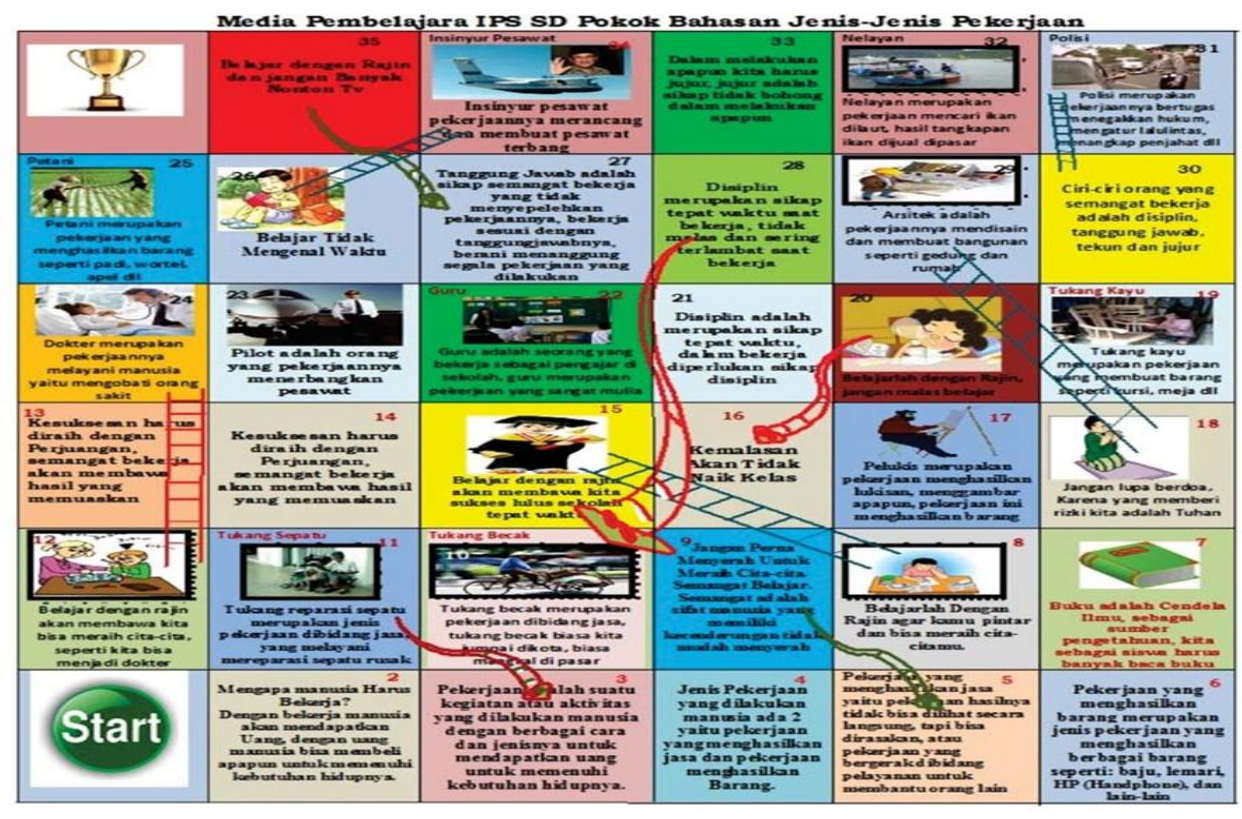

Strategi pengembangan metode ini mengacu pada desain 4D, dimana alur permainan pada ular tangga terdiri dari define, design, develop, dan disseminate. Dan didalam setaip kolom gambar ular tangga terdapat materi pembelejaran IPS. Tujuan alur tersebut digunakan untuk menganalisis karakteristik siswa, analisis kemapuan siswa, dan juga untuk uji coba pembelajaran menggunakan media ular tangga untuk menerik ketertarikan siswa dalam pembelajaran. Dari pengembangan metode.

Ular tangga itu permainan yang menggunakan sebuah dadu untuk menentukan berapa Langkah yang harus dijalani dibidaknya, peramainan ular tangga ini termasuk dalam ketegori permainan papan, sejenis dengan mainan monopoli, ludo dan lainnya. Permaianan ular tangga itu bersifat sangat ringan, sederhana, mendidik, menghibur dan sangat interaktif jika dimainkan bersama-sama dengan cara yang positif.

Karakteristik Media Ular Tangga

Ular tangga termasuk media permainan, permainan disini merupakan kontes para pemain yang berinteraksi satu sama lainnya dengan mengikuti , disini setiap pemainaturan-aturan yang tertentu untuk mencapai sebuah tujuan yang tertentu harus mempunyai komponen-komponen utama diantaranya: (1) adanya pemain-pemain. (2) adanya aturan-aturan permainannya. (3) adanya tujuan permainan yang ingin dicapai.

Ular tangga itu termasuk media permainan yang tidak bisa lepas dari sebuah gambar maupun foto yang ada dalam papan permainan ular tangga, seperti gambar ular dan tangga maupun gambar lain sesuai tema ular tangganya itu. Gambar atau foto itu berfungsi untuk menyampaikan pembelajaran ilmu sosial dasar yang dipelajari dikelas, berdasarkan karakteristik permainan ular tangga ini dapat disimpulkan bahwa ular tangga termasuk media visual yang berbentuk sebuah permainan.

Motivasi Belajar

Menurut (Winkel, 2009) pengertian motivasi belajar adalah segala usaha dalam diri sendiri yang menimbulkan kegiatan belajar, dan menjamin kelangsungan dari kegiatan belajar serta memberi arah pada kegiatan belajar terebut, sehingga mencapai tujuan yang dikehendaki. Menurut sardiman (Astuti et al., 2020; Karim, 2017) ciri ciri orang yang memiliki motivasi belajar bisa di lihat dengan cara ia mengerjakan tugas, menunjukkan ketertarikannya terhadap hal yang dipelajari. Dan sedangkan menurut (Uno, 2008) adanya motovasi belajar di karenakan adanya hal yang 
menarik dalam belajar, sedangkan (Permadi \& Adityawati, 2018) menyatakan media pembelajaran dapat membangkitkan motivasi dan mrangsang siswa untuk belajar. Dapat kita ketahui berdasarkan pendapat para ahli tersebut bahwa menggunkan media pembelajaran dapat menumbuhkan motivasi belajar siswa dalam proses pembelajaran:

\section{Prinsip motivasi belajar}

Supaya peran motivasi belajar dapat berjalan dengan optimal, itu diperukan prinsip motivasi belajar yang harus dilakukan dalam aktivitas pembelajaran. Ada beberapa prinsip dalam motivasi belajar sebagai berikut: 1) Motivasi itu sebagai dasar penggerak yang mendorong sebuah aktivitas belajar, dalam hal ini motivasi belajar itu berperan sebagai dasar penggerak sebuah kegiatan aktivitas peserta didik untuk belajar. 2) Motivasi berupa pujian akan lebih baik dari pada hukuman, dengan memberikan pujian kepada siswa dapat meningkatkan semangat siswa untuk meningkatkan prestasinya atau bisa meningkatkan motivasi belajarnya untuk lebih giat lagi.

\section{Fungsi motivasi belajar}

Motivasi belajar berfungsi sebagai pendorong, pengerak dan penyeleksi perbuatan. Dalam motivasi terdapat tiga fungsi utama sebagai berikut: 1) Motivasi sebagai pendorong perbuatan. Dalam hal ini, motivasi sebagai pendorong untuk mempengaruhi sikap siswa. 2) Motivasi sebagai penggerak buatan. Dengan adanya sebuah motivasi dalam diri siswa, siswa menjadi tergerak untuk melakukan sebuah kegiatan belajar. 3) Motivasi sebgai pengarah perbuatan. Siswa yang mempunyai motivasi dan menyeleksi mana perbuatan yang harus dilakukan dan mana yang harus tidak dilakukan.

\section{Faktor yang mempengaruhi motivasi belajar}

Faktor- faktor yang mempengaruhi motivasi belajar sebagai berikut: 1) Guru : Peran guru sangatlah penting untuk bagaimana cara meningkatkan semangat dan motivasi belajar siswa. Oleh karena itu guru harus bisa mengembangkan metode pembelajaran yang akan digunakan dalam penyampaian materi(Prasetya, 2013; Suprihatin, 2015). 2) Orang tua dan keluarga : Orang tua dan keluarga merupakan motivasi belajar ketika siswa berada dirumah, orang tua hrsu bisa membing dan mendorong anak untuk belajar, sehingga orang tua memahami atau mengatahui karakterisik dan kemampuan anaknya. 3) Masyarakat dan lingkungan : masyarakat dan lingkungan merupakan aspek penting untuk membentuk motivasi siswa. Hal ini di sebabkan oleh ketika teman atau lingkungannya mempunyai semangat untuk belajar maka siswa lainnya juga kana terpengaruhi untuk bersemangat belajar dan menodorong siswa untuk melakukan hal yang sama(Desmita, 2013; Muhibbin Syah, 2013).

Hasil Belajar Siswa: 1) Siswa tidak merasa bosan dan tidak mengantuk saat pembelajaran berlangsung. 2) Siswa lebih bersemangat kembali ketika pembelajaran berlangsung 4) Siswa tidak berbicara sendiri karena siswa terfokus pada alur permainan pembelajaran

\section{KESIMPULAN}

Berdasarkan hasil dari pembahasan di atas dapat di simpulkan bahwa, upaya guru untuk meningkatkan daya tarik motivasi belajar seorang siswa sangatlah penting, maka dari itu guru harus menerapkan strategi atau metode yang menarik dalam proses pembelajaran, agar supaya siswa tidak bosan. Dengan menguunakan metode pembelajaran berbasis permainan Ular Tangga dapat meningkatkan motivasi belajar siswa dan juga siswa tidak bosan saat pembelajaran IPS berlangsung. Karena metode ini siswa tidak hanya belajar saja namun siswa belajar dengan bermain.

Pengembangan media pembeajaran permainan ular tangga dalam pembelajaran ilmu pengetahuan sosial (IPS) valid, media pemeblajaran permainan ular tangga ini dalam pembelajaran IPS bermotivasi hasil belajar siswa meningkat dengan kriteria memotivasi belajar siswa dalam pembelajaran IPS meningkat dengan sempurna, dengan menerapkan media permainan ular tangga seperti ini.

Berdasarkan hasil pembahasan dapat dikemukakan bahwa sekolah dasar / madrasah ibtidaiyah sebagai tempat belajar bagi anak-anak, dalam sebuah kegiatan proses belajar dan 
mengajar dimana anak-anak sering mengalami kebosanan, sehingga seorang guru itu diharapkan mampu mengeola kelas dengan baik dan sekereatif mungkin. Dalam mengatasi setiap sebuah permasalahan pembelajaran, salah satu alternative menyelesaikan permasalahan tersebut dengan melalui media pembelajaran permainan ular tangga seperti ini.

\section{REFERENSI}

Abidin, Y. (2014). Desain sistem pembelajaran dalam konteks kurikulum 2013 (Cetakan kesatu). Refika Aditama.

Alma, B. (2013). Kewirausahaan. Bandung: Alfabeta.

Aprilianto, A., \& Mariana, W. (2018). Permainan Edukasi (Game) Sebagai Strategi Pendidikan Karakter. Nazhruna: Jurnal Pendidikan Islam, 1(1), 139-158. https://doi.org/10.31538/nzh.v1i1.47

Archard, D. (2002). Children, Multiculturalism and Education. In D. Archard \& C. M. Macleod (Eds.), The Moral and Political Status of Children (pp. 150-158). Oxford University Press.

Arumsari, D. (2017). Pengaruh Media Pembelajaran Dan Keterampilan Pengelolaan Kelas Terhadap Prestasi Belajar Siswa SMK Negeri 5 Madiun. Assets: Jurnal Akuntansi Dan Pendidikan, 6(1), 13-25. https://doi.org/10.25273/jap.v6i1.1290

Astuti, J., Novita, M., \& Ismail, M. S. (2020). Peningkatan Motivasi Belajar Menggunakan Contextual Teaching and Learning di Madrasah Ibtidaiyah Swasta Raudhatul Mujawwidin Tebo. Jurnal Educative: Journal of Educational Studies, 5(1), 16-28. https://doi.org/10.30983/educative.v5i1.1630

BK, S. M., Alauddin \&. Muh Khaerul Ummah. (2018). Perencanaan Pembelajaran Kontemporer Berbasis Penerapan Kurikulum 2013. Deepublish.

Darmawan, D. (2014). Inovasi Pendidikan, Pendekatan Praktik Teknologi Multimedia dan Pembelajaran Online (ketiga). PT Remaja Rosdakarya.

Desmita. (2013). Psikologi perkembangan. PT Remaja Rosdakarya.

John W, S. (2015). Psikologi Pendidikan (Tri Wibowo BS, Trans.; 6th ed.). Prenada Media Grup.

Johnson, R. T., \& Johnson, D. W. (2008). Active learning: Cooperation in the classroom. The Annual Report of Educational Psychology in Japan, 47, 29-30.

Karim, A. (2017). Meningkatkan Motivasi Belajar Pendidikan Sejarah Kebudayaaan Islam (Ski) Melalui Metode Pembelajaran Mind Mapping. QUALITY, 1(2).

Kesuma, D. (2011). Pendidikan karakter: Kajian teori dan praktik di sekolah. PT Remaja Rosdakarya.

Muhibbin Syah. (2013). Psikologi Pendidikan dengan pendekatan baru (18th ed.). Remaja Rosdakarya.

Ngalim, P. (2006). Ilmu Pendidikan Teoritis dan Praktis (17th ed.). Remaja Rosdakarya.

Permadi, B. A., \& Adityawati, I. A. (2018). Pengembangan Bahan Ajar Tematik Berbasis Islam \& Kearifan Lokal Kelas Iv Min Seduri \& Mis Nurul Amal Kabupaten Mojokerto. Ną̧runa: Jurnal Pendidikan Islam, 1(1), 122-138. https://doi.org/10.31538/nzh.v1i1.61

Prasetya, B. (2013). Kompetensi Kepribadian Guru Pai Dalam Memotivasi Belajar Siswa. Edukasi: Jurnal Pendidikan Islam, 1(2), 225-238. http://ejournal.staimtulungagung.ac.id/index.php/EDUKASI/article/view/171

Rosyad, A. M., \& Maarif, M. A. (2020). Paradigma Pendidikan Demokrasi Dan Pendidikan Islam Dalam Menghadapi Tantangan Globalisasi Di Indonesia. Naz̧runa: Jurnal Pendidikan Islam, 3(1), 75-99. https://doi.org/10.31538/nzh.v3i1.491

Schweitzer, F., \& Schreiner, P. (2020). International Knowledge Transfer in Religious Education-A Manifesto for Discussion. Religious Education, 115(1), 10-14. https://doi.org/10.1080/00344087.2019.1677988

Suprihatin, S. (2015). Upaya Guru Dalam Meningkatkan Motivasi Belajar Siswa. Promosi Jurnal Pendidikan Ekonomi), 3(1). https://doi.org/10.24127/ja.v3i1.144 
Supriyanto, D. (2018). Pengaruh Penggunaan Media Pembelajaran Berbasis E-Learning. MODELING: Jurnal Program Studi PGMI, 5(1), 112-129. http://jurnal.stitnualhikmah.ac.id/index.php/modeling/article/view/313

Triyanto, E., Anitah, S., \& Suryani, N. (2013). Peran Kepemimpinan Kepala Sekolah dalam Pemanfaatan Media Pembelajaran Sebagai Upaya Peningkatan Kualitas Proses Pembelajaran. Teknologi Pendidikan, 1(2), 226-238.

Uno, H. B. (2008). Teori Motivasi \& Pengukurannya: Kajian \& Analisis Di Bidang Pendidikan.

Utari, U., \& Degeng, I. N. S. (2016). Pembelajaran tematik berbasis kearifan lokal di sekolah dasar dalam menghadapi Masyarakat Ekonomi Asean (MEA). Jumal Teori Dan Praksis Pembelajaran IPS, 1(1), 39-44.

Winkel, W. S. (2009). Psikologi Pengajaran (10th ed.). Media Abadi. 